\title{
Arhiv za likovne umjetnosti Hrvatske akademije znanosti i umjetnosti: 1937. - 2016.
}

Der-Hazarijan Vukić, Andreja

Source / Izvornik: Institucije povijesti umjetnosti : zbornik 4. kongresa hrvatskih povjesničara umjetnosti, 2019, 81 - 90

Conference paper / Rad u zborniku

Publication status / Verzija rada: Published version / Objavljena verzija rada (izdavačev PDF)

https://doi.org/10.31664/z4khpu.10

Permanent link / Trajna poveznica: https://urn.nsk.hr/urn:nbn:hr:254:378414

Rights / Prava: Attribution 4.0 International/Imenovanje 4.0 međunarodna

Download date / Datum preuzimanja: 2023-04-26

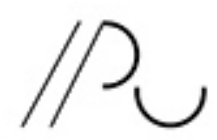

INSIITUTR ZA POVIJESTUMJETNOST
Repository / Repozitorij:

PODEST - Institute of Art History Repository

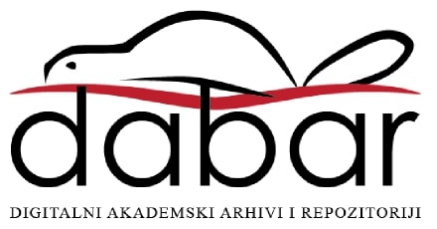




\section{Arhiv za likovne umjetnosti Hrvatske akademije znanosti i umjetnosti: I937.-2016.}

Osnivanjem Gipsoteke r937. godine, ${ }^{1}$ a unutar nje i Arhiva za domaću likovnu umjetnost ${ }^{2}$ kao pomoćne zbirke, Antun $\operatorname{Bauer}^{3}$ (sl. I) odgovorio je kulturnim potrebama vremena i sredine, kojih u tom trenutku sama sredina još nije bila svjesna. Kulturnom vizionaru bilo je neshvatljivo da potkraj tridesetih godina prošlog stoljeća u Hrvatskoj ne postoji muzej gipsanih odljeva i modela kakve su imali svi veći europski gradovi, kao ni to da postojeće muzejske i galerijske ustanove u zemlji ne raspolažu sustavno uređenim arhivima za „stručni studij suvremene domaće umjetnosti”. 4 Taj je brisani prostor Bauer odlučio ispuniti cjelovito zamišljenim projektom Gipsoteke, muzeja koji će zahvaljujući svojim zbirkama omogućiti istraživanja unutar nacionalne povijesti umjetnosti.

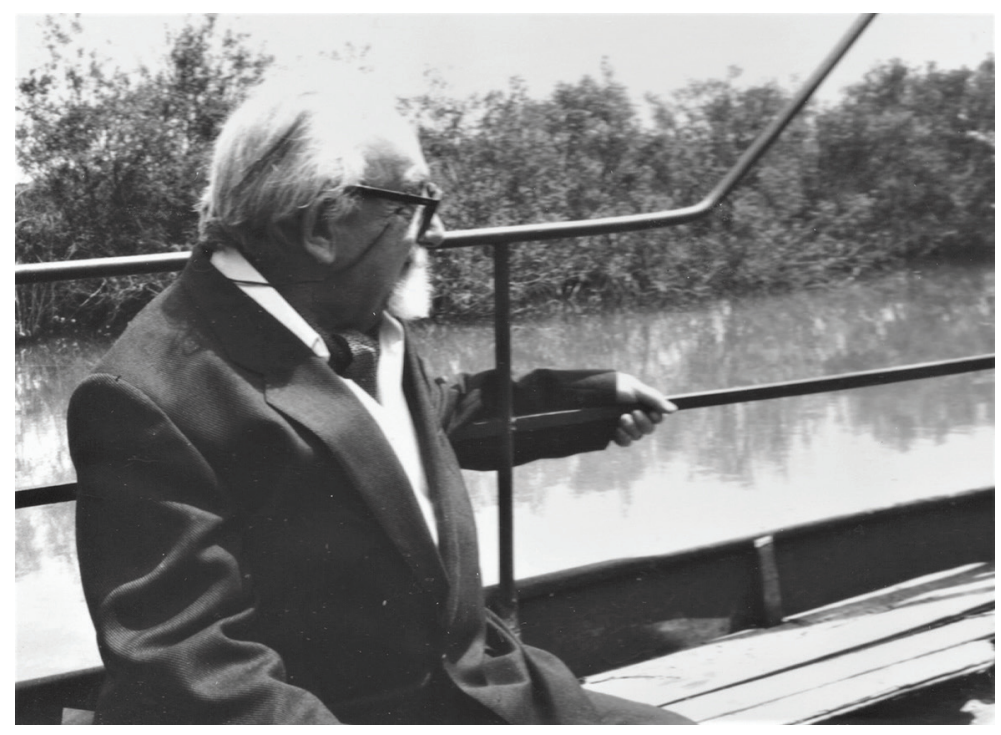

\section{Andreja Der-Hazarijan Vukić}

Arhiv za likovne umjetnosti Hrvatska akademija znanosti i umjetnosti adhv@hazu.hr

(D) https://orcid.org/oooo-ooo2-8362-4542
I „Ekonomski odjel gradskog vijeća odlučio je na sjednici od 2I. Io. I937. da općina grada Zagreba besplatno preuzme od prof. Bauera Gipsoteku, te istu pohrani na doličnom mjestu." Zapisnik sjednice Gradskog vijeća Općine grada Zagreba br. 7770 PrsI937, 29. listopada I937., str. 300

2 Kao godine osnutka Arhiva za likovne umjetnosti navode se uglavnom I943. ili r944.: prva kao godina kada je sakupljenu dokumentacijsko-fotografsku zbirku Antun Bauer darovao Gipsoteci, a druga zbog službenog odgovora Gradskog poglavarstva u kojem se prihvaća donacija, a koji nosi datum II. kolovoza I944. U ovom radu godinu osnutka arhiva pomičemo u I937., godinu njegova začetka, na temelju podnaslova u rukopisu Antuna Bauera Skica rada i razvitka Arhiva za suvremenu umjetnost sa knjižnicom i fotolaboratorijem gradske Gipsoteke kroz deset godina, od postanka do danas. ANTUN BAUER, DUŠKO KEČKEMET, Gipsoteka: Arhiv za domaću likovnu umjetnost, I937.-I947., Zagreb, I948. (rukopis bez paginacije), Arhiv za likovne umjetnosti HAZU (dalje: ARLIKUM HAZU), Ostavština Antuna Bauera.

3 Antun Bauer (Vukovar, IgII.-Zagreb, 20oo.), povjesničar umjetnosti, arheolog, muzeolog. Svojim je donacijama uz Gipsoteku i Arhiv za likovne umjetnosti utemeljio i Galeriju umjetnina u Osijeku, Muzejski dokumentacijski centar, Galeriju umjetnina i Zbirku Bauer Gradskog muzeja u Vukovaru. Dao je poticaj osnivanju studija muzeologije te pokrenuo izdavanje muzeoloških časopisa. Cjeloživotnim djelovanjem neumorno je prikupljao, čuvao i promovirao hrvatsku kulturnu i umjetničku baštinu. Iako je njegovo nasljeđe ugrađeno u same temelje naših umjetničkih institucija, do danas za taj nemjerljiv rad nije dobio zasluženo i dostojno priznanje.

4 ANTUN BAUER, Gipsoteka I937.-1947. (umnoženi strojopis), Zagreb, I948., I2, ARLIKUM HAZU, Ostavština Antuna Bauera.
Slika I

Antun Bauer u čamcu na Savi, I99I. Fotoalbum s postavljanja spomen-ploče Ivi Kerdiću u Davoru, 29. svibnja I99I., ARLIKUM HAZU, Ostavština Antuna Bauera 

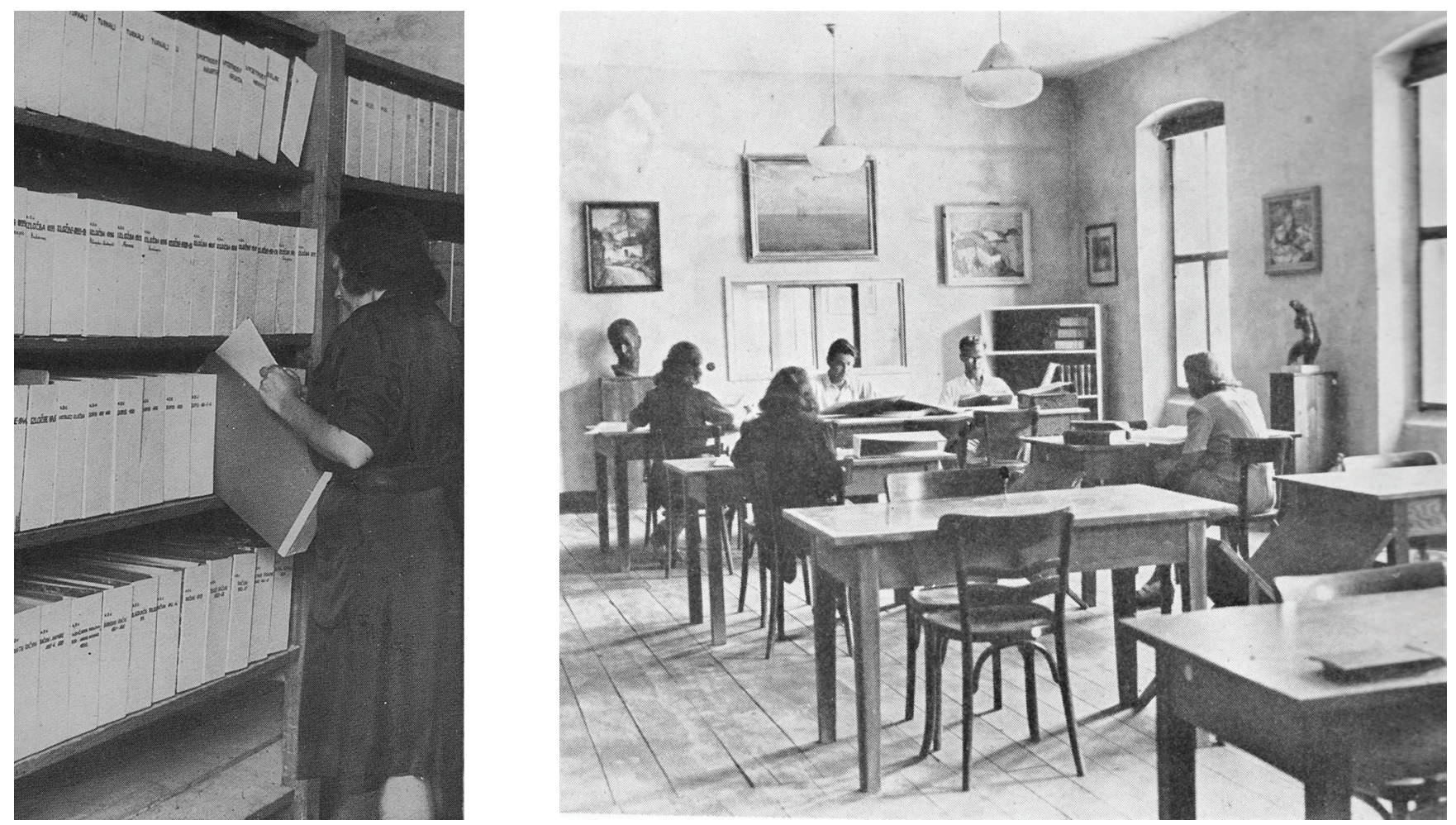

Slika 2

Dokumentacija Arhiva za domaće umjetnosti u Gipsoteci, oko I943. fotografija preuzeta iz: ANTUN BAUER, Gipsoteka I937.-I947., umnoženi strojopis, Zagreb, I948., ARLIKUM HAZU, Ostavština Antuna Bauera
Slika 3

Čitaonica Arhiva za domaće umjetnosti u Gipsoteci, oko I946.

fotografija preuzeta iz: ANTUN BAUER, Gipsoteka I937.-I947., umnoženi strojopis, Zagreb, I948., ARLIKUM HAZU, Ostavština Antuna Bauera
Osnovni cilj Gipsoteke bio je prikupljanje gipsanih modela i odljeva ponajprije domaćih majstora od najstarijih vremena do moderne plastike, sa svrhom zaokruživanja pojedinačnih kiparskih opusa. Usporedno s modelima i odljevima sabirana je i pomoćna dokumentarna građa, kojom su se upotpunjavala znanja o postojećim djelima, ali i ilustrirala ona koja su nedostajala u zbirkama Gipsoteke. U tu su svrhu prikupljani novinski članci, reprodukcije djela, arhivski podaci, originalne skice i crteži, kao i fotografije izložaba, privatnih atelijera i javnih spomenika. Ubrzo se žarište interesa širi i na slikare, jer se pokazalo da se uvid u nacionalnu umjetničku produkciju dobiva jedino praćenjem cjelokupne umjetničke prakse, čime je ujedno zacrtan smjer razvoja Arhiva za domaću likovnu umjetnost. ${ }^{5}$ Ta rastuća zbirka dijelila je sudbinu Gipsoteke u brojnim selidbama i privremenim lokacijama, ${ }^{6}$ do konačnog smještaja u Medvedgradskoj 2, kamo zbirka dokumentacije useljava r94I. godine ${ }^{7}$ kao potpuno nesređena građa $u$,pet dvokrilnih ormara". ${ }^{8}$ S njezinim sređivanjem započelo se u jesen r942. godine uz pomoć obveznica Radne službe, koje su
5 „Takav arhiv naše suvremene umjetnosti koji se nadovezuje na bogati arhiv naše starije umjetnosti pri Konzervatorskom zavodu u Zagrebu ima u tom obliku svoje puno opravdanje i sve uvjete za svoj razvitak kao zrela i zaokružena cjelina koja nema tek sporedni karakter, već primarni i od neobične važnosti za rad i za razvoj naše povijesti umjetnosti." ANTUN BAUER, DUŠKO KEČKEMET (bilj. 2)

6 Po preuzimanju Gipsoteke od Gradskog poglavarstva, zbirke su smještene u drveno spremište na gradskom majuru u Bednjanskoj 23, odakle su zbog premalog i neadekvatnog prostora I939. godine preseljene u bivšu kuću obitelji Burgstaller na Ksaverskoj cesti 2I. Tu se započinje i s prvim sustavnim popravcima skulptura. Iduće godine za trajni i cjeloviti smještaj Gipsoteke dobivena je zgrada bivše tvornice kože u Medvedgradskoj 2, u koju se među posljednjima I94I. godine smješta i zbirka dokumentacije s knjižnicom. ANTUN BAUER (bilj. 4), 2I, 26.

7 Najveći dio zbirke prenesen je u Medvedgradsku 2 godine I940.

8 ANTUN BAUER, DUŠKO KEČKEMET (bilj. 2). 
materijal organizirale prema uputama Antonije Tonke Bauer, ${ }^{9}$ koja od proljeća I940. surađuje u radu Gipsoteke kao volonterka, gdje vodi unutarnji administracijski posao. Posebno se posvetilo sređivanju fotografija, reprodukcija, članaka i bilježaka prema autorima, vremenu i mjestu, koji su se lijepili na kartone te slagali u fascikle da bi se naknadno tako razvrstan materijal sistematizirao. Arhiv za domaću umjetnost ${ }^{10}$ službeno započinje s radom i943. godine, kada prof. Bauer darovnicom prepušta Gipsoteci tako složen materijal, uz uvjet da se nastavi s njegovim prikupljanjem. Istovremenom donacijom ustupa Gipsoteci i zbirku crteža, skica, studija i grafika suvremenih domaćih umjetnika, koje je s vremenom prikupio. ${ }^{11}$ Uzimajući u obzir lakši pristup u radu s prikupljenom dokumentacijom, arhivski je materijal sistematiziran i razdijeljen u šest grupa/zbirki: Fototeku suvremene domaće umjetnosti zajedno s člancima, katalozima, reprodukcijama i bilješkama iz tog područja, složenu prema autorima (domaćim i stranim koji su djelovali u našoj zemlji); Kartoteku izložaba naše suvremene umjetnosti: fotografije, reprodukcije, članci i katalozi, bilješke o izložbama s kraja I9. i početka 2o. stoljeća; Zbirku studija, crteža, skica i grafika suvremenih domaćih umjetnika; Fototeku negativa i dijapozitiva; Arhiv strane umjetnosti, osobito suvremene, u reprodukcijama i člancima kao priručni komparativni materijal; Knjižnicu s djelima iz područja domaće i strane umjetnosti. Oformljen je i fotolaboratorij kao i čitaonica Arhiva, namijenjena stručnoj javnosti i samim umjetnicima, u kojoj je ujedno bio smješten materijal arhiva na raspolaganju za stručni i znanstveni studij. Arhiv je smješten na prvom katu ulične zgrade, gdje je obuhvaćao spremište za arhivski materijal (sl. 2), dvije radne sobe za kustosa i arhivskog tehničara te čitaonicu (sl. 3) opskrbljenu potrebnim namještajem. Potpuno osposobljen za rad s korisnicima, Arhiv za domaću umjetnost otvoren je u proljeće ig46. godine. ${ }^{12}$

Bauer je Arhivu zadao još jednu ambicioznu zadaću: prikupljanje svih članaka i reprodukcija publiciranih u hrvatskim tiskovinama od početka njihova izlaženja. U tu se svrhu pristupilo sustavnu pregledavanju svih hrvatskih novina i časopisa koji su izlazili od prve polovine ig. stoljeća, prijepisu članaka te fotografiranju reprodukcija. Na temelju svih pregledanih i popisanih članaka s područja likovne umjetnosti stvoren je korpus sveobuhvatne bibliografije, objedinjene u 30 svezaka s ukupno 7500 stranica pod naslovom Bibliografija i građa za umjetnost $i$ srodne struke (sl. 4). Razrađen je i sustav sortiranja članaka, njihovo grupiranje uz autore ili pak izložbe na koje su se odnosili. Tako oblikovani fascikli slagani su kronološki ili tematski, s pridodanim fotografijama ili reprodukcijama djela. Fototeka se osim reprodukcijama iz časopisa popunjavala i originalnim fotografijama djela snimanih u atelijerima,

Slika 4

Bibliografija i građa za umjetnost i srodne struke, naslovnica ARLIKUM HAZU, Knjižnica
9 Antonija Tonka Bauer, supruga i suradnica Antuna Bauera (Zagreb, I9ı3.-Zagreb, 2002.), diplomirana pravnica, apsolventica povijesti umjetnosti, doktorica bibliotekarstva. U Gipsoteci je bila zadužena za administrativne poslove te obradu i sistematizaciju likovne dokumentacije.

Io U Bauerovim zapisima nailazimo na variranje imena Arhiva, i to: Arhiv za domaću umjetnost, Arhiv za domaću likovnu umjetnost, Arhiv za suvremenu umjetnost.

II Zbirka je preuzeta zapisnički, s komisijom koja je sastavljena izvan Gipsoteke, a u kojoj su bili prof. Franjo Buntak, upravitelj Gradskog muzeja, prof. Marija Hanževački, kustosica Gradskog muzeja, Slavko Šohaj i Pavao Perić, akad. kipar. Zapisnik je sačinjen 3o. travnja I943. godine uz iscrpan popis svih pojedinih predmeta koji su se nalazili u toj zbirci. ANTUN BAUER, DUŠKO KEČKEMET (bilj. 2).

I2 U istom zapisu Bauer navodi da je Arhiv otvoren $u$ siječnju r944. godine. ANTUN BAUER (bilj. 4), 66.

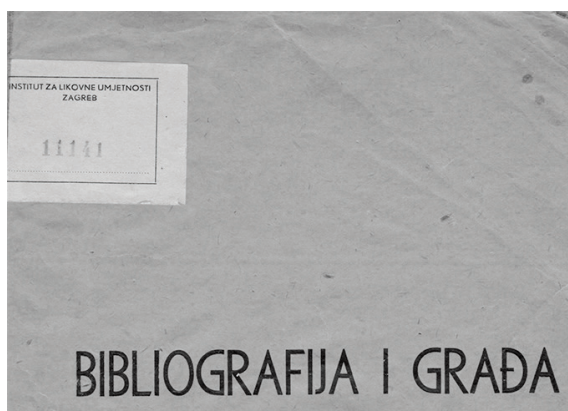

ZA UMJETNOST I SRODNE STRUKE

I. 


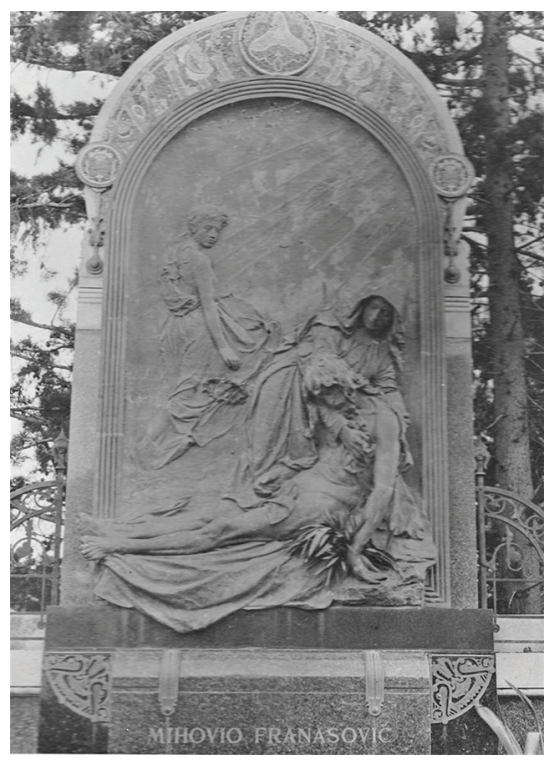

Slika 5

Ivan Rendić, Nadgrobni spomenik Mihovila

Franasovića, Supetar, Brač ARLIKUM HAZU, Fototeka-I. Rendić, K 286

foto: Duško Kečkemet, I948.

\section{Slika 6}

Izložba Hrvatskog društva umjetnosti I9o2.

Umjetnički paviljon u Zagrebu, ARLIKUM HAZU, Arhiv HDU, K2

Slika 7

Iskaznica Kluba likovnih

umjetnica

ARLIKUM HAZU, Arhiv KLU, KI

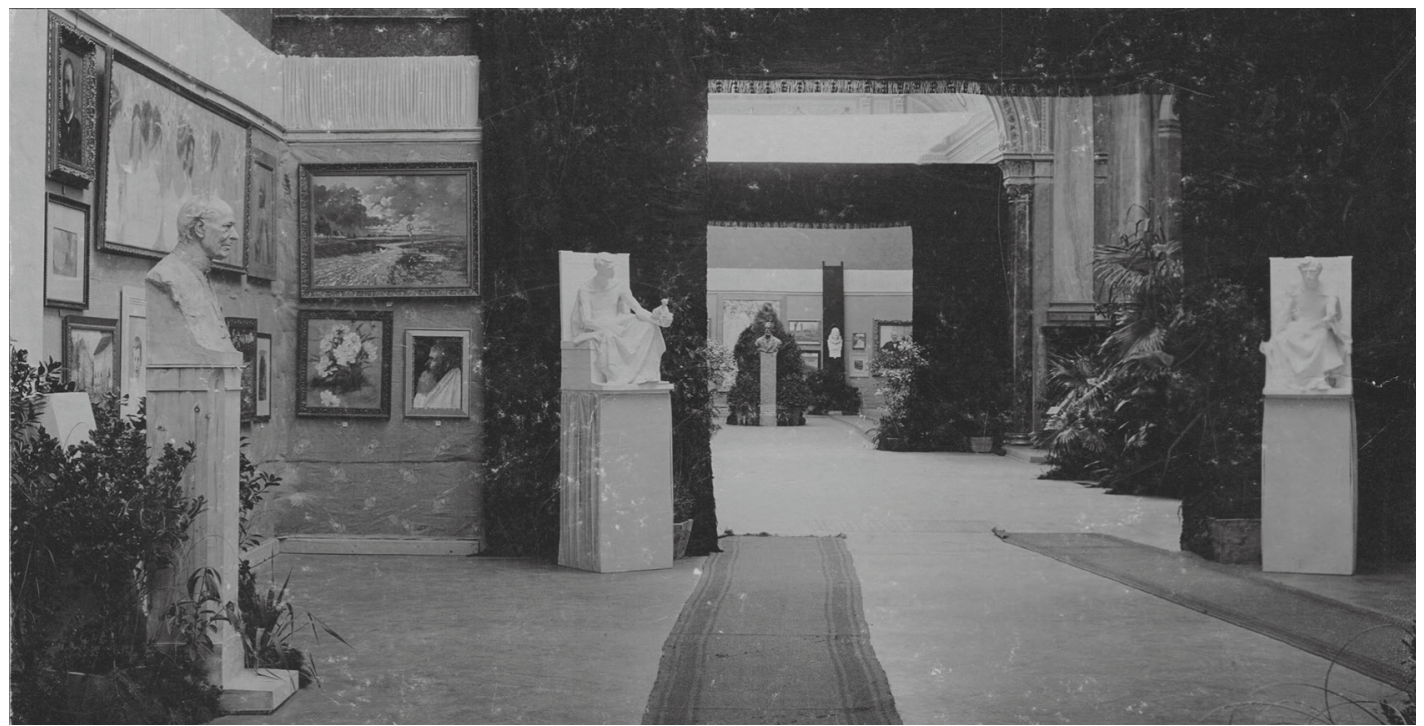


zbirkama ili na izložbama (sl. 5). Uz dokumentaciju, okosnicu Arhiva činile su osobne ostavštine umjetnika, dokumentacije umjetničkih društava i strukovnih umjetničkih udruženja. Među prvim većim akvizicijama te vrste građe bio je arhiv Hrvatskoga društva umjetnosti (sl. 6), nađen na odlagalištu staroga papira u lipnju I945. ${ }^{13} \mathrm{O}$ brzini popunjavanja dokumentacijom govore podaci o stanju Arhiva i fototeke I948. godine koje Bauer navodi u svom rukopisu. Arhiv je te godine imao 840 registriranih autora od kojih 588 ,imaju stanovito gradivo". Fototeka je bila raspoređena u 2297 fascikala s oko 23.0oo komada fotografija i reprodukcija, članaka itd., od kojih je oko 460 reprodukcija u boji. Arhivska građa uključivala je I2 fascikala Arhiva Društva za izgradnju Doma likovnih umjetnika, I 76 fascikala Arhiva Hrvatskog društva umjetnosti, 40 fascikala Kluba likovnih umjetnica (sl. 7), 265 fascikala Arhiva Ive Kerdića, zapečaćen arhiv slikara Butozana te tada još nesređen Arhiv Umjetničkog salona Ullrich. ${ }^{14} \mathrm{Na}$ opsežnim poslovima radili su povjesničari umjetnosti, kojima su pomagali i obveznici Radne službe. Među njima su u razdoblju od I945. do I950. godine ovdje započeli svoj radni vijek i priznati stručnjaci naše povijesti umjetnosti kao što su Lelja Dobronić, ${ }^{15}$ Duško Kečkemet ${ }^{16}$ i Doris Baričević. ${ }^{17}$

Do zahtjevnog angažmana Gipsoteke i njezina ravnatelja Bauera dolazi potkraj četrdesetih, kada na inicijativu i u suradnji s Jugoslavenskom akademijom znanosti i umjetnosti započinju pripreme za veliku Izložbu srednjovjekovne umjetnosti Jugoslavije, predviđenu za ožujak r95o. godine u Parizu, za koju su se u Gipsoteci odlijevali spomenici hrvatske srednjovjekovne umjetnosti. Reprezentativna i ambiciozno zamišljena izložba bila je političko-propagandni projekt Miroslava Krleže, ${ }^{18}$ koja je afirmiranjem sveukupne jugoslavenske umjetničke baštine iz razdoblja srednjeg vijeka trebala potvrditi vrijednosti naših civilizacijskih dometa te tako prevladati postojeće predrasude Zapada. Osim velikog inozemnog uspjeha, izložba se posredno pokazala ključnom za sudbinu Gipsoteke, kao i za sama Antuna Bauera. ${ }^{19}$ Naime već potkraj iste, I950. godine, ${ }^{20}$ Gipsoteku zajedno s Arhivom za domaću umjetnost od zagrebačkog Gradskog narodnog odbora preuzima Jugoslavenska akademija znanosti i umjetnosti. S ulaskom Gipsoteke i njezinih zbirki u okvir Akademije javio se problem organizacije ustanova unutar Odjela za likovne umjetnosti i muziku JAZU. $\mathrm{U}$ tu je svrhu osnovan Institut za likovne umjetnosti ${ }^{21}$ kako bi se objedinio i organizirao složeni posao koordiniranja muzejsko-istraživačkih ustanova koje su ušle u njegov okvir: Stara galerija, Moderna galerija, Grafički kabinet, Gipsoteka, Kabinet za medalje, Zavod za arhitekturu i urbanizam, Arhiv za likovne umjetnosti, Biblioteka i Restauratorski zavod. Zadaće Instituta bile su znanstveno istraživanje, sabiranje i čuvanje umjetničkih spomenika, sistematski rad na prikupljanju i obradi građe za povijest umjetnosti, te organizacija izdavačke djelatnosti, kao i međuinstitucionalna i međunarodna suradnja, ostvarene objedinjavanjem potencijala svih svojih jedinica. Za prvog ravnatelja Stručnog vijeća Instituta imenovan je Krsto Hegedušić. Tijekom 1952. godine Arhiv za likovne umjetnosti
I3 Arhiv DHU, raspoređen u I76 fascikala, sadržavao je podatke o prvom djelovanju Kršnjavoga na polju organizacije likovnog života u Hrvatskoj te o pedeset godina rada Društva. Nakon prelaska Gipsoteke i Arhiva pod JAZU, taj je materijal samo dijelom pohranjen u Arhivu za likovne umjetnosti, dok je veći dio privremeno smješten u Modernu galeriju, koja je tada također bila dio Odjela za likovne umjetnosti JAZU. Unatoč dugogodišnjim nastojanjima da se dokumentacija ponovno objedini unutar Arhiva za likovne umjetnosti, do toga nije došlo. Danas se taj dio građe nalazi u Hrvatskom državnom arhivu u fondu Kršnjavi i Hrvatsko društvo umjetnosti (I869.-I9I8.).

I4 Prvi otkup arhiva Umjetničkog salona Ullrich bio je I948. godine. Drugi dio te vrijedne i raznolike dokumentacije otkupljen je r955. i danas čini najveći i najčešće korišten fond unutar Zbirke ostavština.

I5 Lelja Dobronić (Zagreb, I920.-Zagreb, 2006.) u Gipsoteci radi kao kustosica od I944. do I947. godine, na usustavljivanju građe Arhiva te na izradi niza Bibliografija i grade za umjetnost $i$ srodne struke.

I6 Duško Kečkemet (Supetar, I923.) u Gipsoteci je radio od I945. do I949. godine. Započinje još za vrijeme studija povijesti umjetnosti kao volonter, a od I947. bio je u svojstvu asistenta-kustosa Arhiva za suvremenu umjetnost. Vodio je arhivsku zbirku dokumentacije, ali i fotografski dokumentirao umjetničke izložbe, same umjetnike i njihove atelijere. Bio je zadužen za Odjel novije skulpture. JOZEFINA DAUTBEGOVIĆ Personalni arhiv MDC-a: dr. sc. Duško Kečkemet, u: Informatica museologica, 36/3-4 (2007.), II6.

I7 Doris Baričević (Graz, I923.-Zagreb, 2oI6.) neposredno po završetku studija dolazi u Gipsoteku kao volonterka, a od I949. godine zaposlena je kao kustosica u Gipsoteci u zbirkama Arhiva, u kojem ostaje i nakon njegova prelaska u JAZU, poslije HAZU. Baveći se paralelno znanstvenim i stručnim radom, vodila je i koordinirala rad u Arhivu za likovne umjetnosti do mirovine r993. godine, koju je dočekala u zvanju znanstvene savjetnice.

I8 Miroslav Krleža organizaciji izložbe pristupio je u svojstvu potpredsjednika Jugoslavenske akademije $\mathrm{u}$ kojoj se $\mathrm{u}$ to vrijeme velikim dijelom kreirala strategija kulturnog i znanstvenog razvoja novonastale države. Bio je član organizacijskog odbora te autor predgovora kataloga izložbe s podnaslovom Plaidoyer pro domo.

I9 Nakon ulaska Gipsoteke u sastav JAZU, Bauer ostaje njezinim ravnateljem do I952. godine, kada nakon optužbi o propustima u vođenju zbirki te financijskih neusklađenosti s odlukama JAzU dobiva otkaz. Sam Bauer mnogo je pisao i često govorio o tim događajima kao i o razlozima koji su doveli do njih, osobito o sukobu s Miroslavom Krležom i Krstom Hegedušićem.

20 Akademija preuzima Gipsoteku 23. listopada I95o., koja od I. siječnja r95I. godine financijski i administrativno postaje dijelom JAZU.

2I Odjel za likovne umjetnosti i muziku na svojoj 5 sjednici održanoj 25. travnja I95I. godine donio je zaključak da se osnuje Umjetnički institut. Taj je zaključak Odjela odobrilo Predsjedništvo Akademije na sjednici održanoj 29. travnja I951. te je odobren izbor akademika Krste Hegedušića za ravnatelja Instituta. Na 6. sjednici Odjela 2I. svibnja I95I. predložen je pravilnik i naziv Institut za likovne umjetnosti. Na Io. sjednici Odjela održanoj 6. studenoga I95I. izabran je za predsjednika Instituta arh. Drago Galić umjesto Hegedušića. Pravilnik Instituta donesen je 27. prosinca I95I. godine. Ljetopis Jugoslavenske akademije znanosti $i$ umjetnosti za godine I95I-I952, knjiga 58, Zagreb, I953., I63. 
administrativno se odvaja od Gliptoteke i postaje samostalna radna ustanova Instituta za likovne umjetnosti JAZU. Kako se unutar Arhiva nalazila i zbirka originalnih grafika, ulja, crteža i skica, tom je prigodom osnovana Komisija VII. odjela ${ }^{22} \mathrm{za}$ selekciju grafičkog materijala iz Arhiva za domaću umjetnost Gliptoteke, zadužena nadgledati selektiranje materijala iz Arhiva koji je po svojem karakteru ušao u fundus Grafičkog kabineta, Moderne galerije, Zavoda za arhitekturu i urbanizam, ali i u neke muzeje i galerije izvan sastava JAZU. S druge strane, u sastav Arhiva ušli su svi arhivi područnih ustanova Odjela. ${ }^{23}$ Taj je proces završen u siječnju r953. godine ${ }^{24}$ predajom selektirana i znatno reducirana materijala Upravi Arhiva za likovne umjetnosti, s potpisom direktora Gliptoteke prof. Miroslava Montanija. Arhivu su pripali kartoteka izložaba, kartoteka domaćih umjetnika, fototeka, arhivalije, novine, kartoteka likovnih izložaba, inventarne knjige te priručna knjižnica, dok je stručna biblioteka predana središnjoj knjižnici Instituta. Arhiv za likovne umjetnosti dobiva i smjernice budućega rada prema s glavnim zadacima:

- prikupljanje, sređivanje i čuvanje arhivalija pojedinih umjetnika, ustanova i udruženja, u odnosu djelovanja na razvoju likovne umjetnosti u Hrvatskoj;

- prikupljanje, sređivanje i čuvanje kataloga i pozivnica na izložbe, kao i vođenje evidencije o izložbama u FNRJ;

- prikupljanje, sređivanje i čuvanje fotografija pojedinih umjetničkih djela kako bi Arhiv mogao pružiti uvid u razvoj i dostignuća naše likovne umjetnosti;

- rad na dokumentaciji, prikupljanju štampe, reprodukcija i klišeja;

- prikupljanje podataka o životu i radu umjetnika, rad na bibliografiji članaka iz dnevne štampe i časopisa.

Time je postavljena baza na kojoj će se nastaviti rast i razvoj postbauerovskog Arhiva za likovne umjetnosti. Proširenjem opsega djelatnosti na prikupljanje izložbene i biografske dokumentacije s područja cijele Jugoslavije Arhiv dobiva karakter nacionalnoga referentnog dokumentacijskog centra za područje likovne umjetnosti. Prvi zadatak bio je stručna inventarizacija cjelokupnoga predanog materijala. Bio je to zahtjevan posao na čiju je dinamiku uvelike utjecalo i smanjivanje dotadašnjeg personala, zbog preustroja jedinica, pa je tako u Arhivu od kolovoza r952. godine bila zaposlena jedino Doris Baričević kao kustosica. U siječnju I953. rukovoditeljica Arhiva za likovne umjetnosti postaje Danica Śvalba, ${ }^{25}$ a u rujnu se Arhiv preseljenjem na drugi kat kuće u Demetrovoj I8 i fizički odvaja od Gliptoteke. Po preseljenju pristupilo se reorganizaciji i osuvremenjivanju rada Arhiva kako bi se djelovanjem uskladio sa srodnim europskim ustanovama. Uvode se novine u sređivanju preuzetoga materijala, koji se raspoređuje, evidentira i pohranjuje prema novim kriterijima sa svrhom jasnijeg definiranja zbirki, a uvodi se i sustavna evidencija o obrađenoj građi i obavljenu poslu. Jedan od prvih koraka nove uprave Arhiva, uz organizaciju stručnog rada, bila je uspostava mreže kontakata s umjetnicima, muzejima, galerijama te umjetničkim udruženjima. Njihovi su izložbeni materijali pohranjivani
22 Članovi komisije bili su Krsto Hegedušić (tajnik Odjela za likovne umjetnosti i muziku), Tomislav Krizman (akademik), Ljubo Babić (akademik), Jerolim Miše (dopisni član), Stella Ubel (ravnateljica Grafičkog kabineta), Miroslav Montani (v. d. direktora Arhiva) i Doris Baričević (kustosica Arhiva).

23 Ljetopis Jugoslavenske akademije znanosti i umjetnosti za godinu I953, knjiga 6o, Zagreb, I955., 84.

24 Zapisnik o izvršenju primopredaje materijala Arhiva za likovne umjetnosti Upravi Arhiva za likovne umjetnosti Instituta za likovne umjetnosti, 26. siječnja I953. ARLIKUM HAZU, Registraturno gradivo, I953.

25 Danica Švalba rođ. Stajić (Pljevlja, I9o5.--?), do 1952. godine prva direktorica Muzeja revolucije naroda Hrvatske. Nakon odlaska s mjesta rukovoditelja Arhiva za likovne umjetnosti I959. radi kao stručna suradnica u Zavičajnom muzeju Rovinja. O njezinu životu poslije, kao ni o datumu smrti, nisam uspjela pronaći podatke. 
u zbirke, a podaci o održanim izložbama evidentirani i objavljivani u Likovnoj kronici Bulletina Instituta za likovne umjetnosti ${ }^{26}$ (sl. 8), koji počinje izlaziti r953. godine. Galerije i muzeji ubrzo su prepoznali Arhiv kao mjesto koje će registrirati njihove aktivnosti, a izložbene materijale učiniti studijskom građom za dalja stručna i znanstvena istraživanja. Na isti je način uspostavljen i kontakt s umjetničkim udruženjima, ${ }^{27}$ ali i samim umjetnicima, koji često posjećuju Arhiv i doniraju dokumentaciju o svojoj umjetničkoj i izlagačkoj djelatnosti. ${ }^{28} \mathrm{U}$ svrhu popunjavanja hemeroteke, neprocjenjivog izvora u praćenju recentnih umjetničkih zbivanja i izradi bibliografije, Arhiv od I952. godine redovito prima glavne republičke dnevne novine, a od I953. u suradnji s Agencijom Jugopress i press clipping jugoslavenske štampe. ${ }^{29}$ Organizaciju nabave kataloga, fotografija izložaba kao i sve ostale dokumentacije o radu Arhiva koordinira Institut uspostavljanjem obaveze dostavljanja takva materijala Arhivu svih svojih jedinica.

U nastojanju da se organizacijski ustroj Arhiva uskladi s međunarodnim normama, upraviteljica Arhiva Danica Švalba i kustosica Doris Baričević upućivane su na studijske posjete specijaliziranim arhivima i dokumentacijskim centrima, ${ }^{30}$ a prikupljena iskustva o načinima sakupljanja materijala, inventarizaciji, opisivanju, opremi, katalogiziranju i razvrstavanju poslužili su za poboljšanje sustava rada u zbirkama Arhiva. Od 1956. do I959. godine pri Arhivu djeluje i Komisija zadužena za „prijedloge i rješavanja stručnih pitanja” u kojoj su bili Vanja Radauš, Danica Švalba, Ivan Bach te Matko Peić. Komisija je na deset održanih sjednica odlučivala o mnogim programskim, ali i praktičnim pitanjima razvoja i djelatnosti Arhiva. ${ }^{31}$ Osuvremenjivanje Arhiva po uzoru na europske

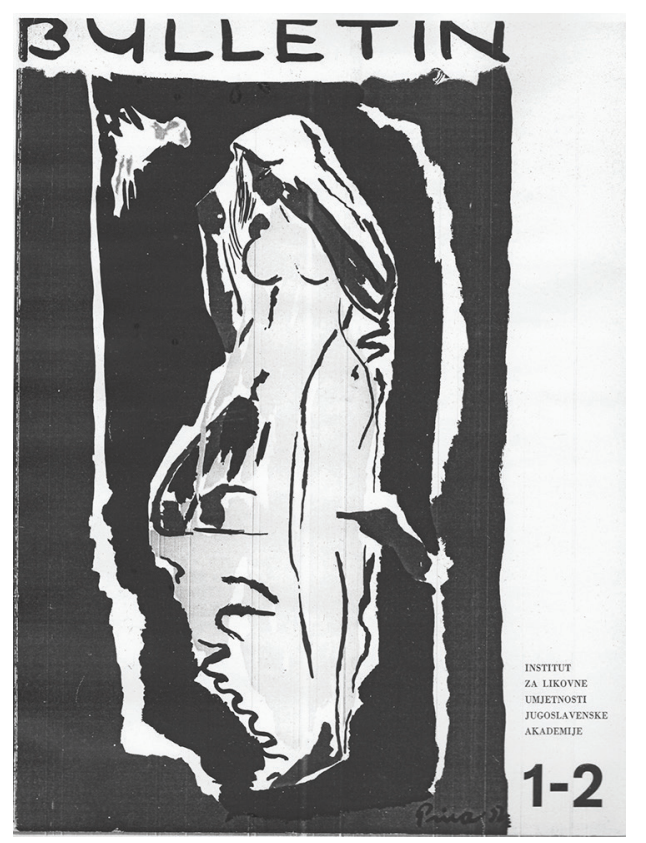

Slika 8

Naslovnica prvog broja Bulletina Instituta za likoune umjetnosti JAZU, I953. ARLIKUM HAZU, Knjižnica
26 Od I953. godine Institut za likovne umjetnosti počinje izdavati Bulletin namijenjen temama o likovnoj umjetnosti i arhitekturi, vezanima uz fondove i aktivnosti svojih galerijskih i stručnih ustanova. Arhiv za likovne umjetnosti uređuje Likovnu kroniku, u kojoj objavljuje popise izložaba održanih u Hrvatskoj, kao i onih inozemnih na kojima izlažu naši umjetnici. Uz popise, donose se podaci o broju posjetitelja, te o broju prodanih radova. Časopis je izlazio $s$ manjim prekidima od I953. do I988. godine, zatim I994., nakon čega je ponovno pokrenut 20II. godine kao Art bulletin (gl. urednik Andrija Mutnjaković). Urednici su bili Jerolim Miše (I953.-I956.), Krsto Hegedušić (I956.-1957.), Ljubo Babić (I957.-1974.), Edo Kovačević (I977. - I988.), Miroslav Begović (I994.) i Andrija Mutnjaković (20II.-danas).

27 Udruženje likovnih umjetnika Hrvatske (ULUH) išlo je i korak dalje, te je od Arhiva redovito tražilo podatke o izlagačkoj aktivnosti članova u svrhu ostvarivanja njihovih strukovnih i socijalnih prava.

28 Neposredno po preseljenju I953. godine, u izvještaju Arhiva zabilježeno je da su Arhiv posjetili Oton Gliha, Milenko Šerban, Zdenka Ostović, Zvonimir Lukinović, Lujo Bezeredi, Petar Salopek i Sonja Kovačić Tajčević. ARLIKUM HAZU, Registraturno gradivo.

29 Riječ je o broju između šest i osam tisuća novinskih izrezaka godišnje. ARLIKUM, Registraturno gradivo.

30 Danica Svalba I954. godine boravi u Parizu na Stage International des Archives pri Nacionalnom arhivu Francuske, dok kustosica Doris Baričević I956. godine boravi u Münchenu u Zentralinstitut für Kunstgeschichte, te I958. u Haagu na VII. ljetnom tečaju iz povijesti umjetnosti u organizaciji Nizozemskog instituta za povijest umjetnosti (RKD Netherlands Institute for Art History, Haag).

3I Upravo je za vrijeme rada Komisije otkupljeno najviše vrijedne građe, a posebno se ističu hemeroteka i fotoarhiv Artura Schneidera (I953.), korespondencija s umjetnicima Antuna Ulricha (I954.), katalozi, novinski članci, fotografije Mirjane Schneider (I957.), fotonegativi djela domaćih umjetnika Radoslava Putara (I958.); zbirka Dušana Plavšića od I56 komada prigodnica (I959.), fotoreprodukcije vlastitih radova Branka Ružića (I958.), bibliografija Vinka Zlamalika (I959.). Također, prema jednom od prijedloga Vanje Radauša, Arhiv je tih godina izradio prvi popis privatnih zbirki umjetnina u Hrvatskoj. 
specijalizirane arhive, institute i dokumentacijske centre tih pedesetih godina može se pripisati činjenici da su umjetnici, članovi Odjela za likovne umjetnosti, iz osobnih ali i političkih razloga, bili osobito zainteresirani za takav oblik centraliziranog institucionalnog praćenja umjetničkog djelovanja, dok je njihova pripadnost političkom establišmentu dodatno olakšavala provođenje većine zamisli. ${ }^{22}$

Po povlačenju prijedloga za registraciju Instituta kao znanstvene ustanove on se ukida, nakon čega dolazi do reorganizacije ustanova koje su dotad bile u njegovu sastavu. Arhiv za likovne umjetnosti prelazi u sastav centralnog Akademijina Arhiva u prosincu I959. godine nakon završene primopredaje cjelokupnog materijala. ${ }^{33} \mathrm{U}$ Arhivu je tada bilo zaposleno troje kustosa zaduženih za pojedine zbirke $^{34}$ te dvije administratorice. Nakon desetljeća konsolidiranja i sistematiziranja rada, šezdesete i sedamdesete donose nove oblike angažmana Arhiva. To se osobito odnosi na načine suradnje s muzejima, galerijama i ostalim ustanovama u kulturi, koji se u tom razdoblju znatno proširuju. Šezdesetih se godina osnivaju muzeji suvremene umjetnosti u svim republičkim središtima, a unutar njih formiraju se dokumentacijski odjeli, u čemu im Arhiv za likovne umjetnosti pruža savjetodavnu i stručnu pomoć, kako o načinima njihovih popunjavanja, tako i o principima vođenja dokumentacije. U tom se smislu osobito intenzivno surađivalo s Muzejom savremene umetnosti iz Beograda, osnovanim ig6o. godine, koji je na temelju Arhivskog fonda popunjavao i stvarao dokumentaciju o suvremenoj jugoslavenskoj umjetnosti. ${ }^{35}$ $\mathrm{Na}$ isti se način ostvarila suradnja i s Modernom galerijom u Ljubljani, Muzejom suvremene umjetnosti u Skopju, Narodnim muzejom u Nišu i Modernom galerijom u Beogradu. Sam Arhiv usustavljenom i obrađenom građom omogućio je novu etapu internog rada, njezinu stručnu i znanstvenu obradu. Publiciraju se dijelovi ostavština, obrađuju pojedine umjetničke pojave. ${ }^{36}$ Sedamdesete godine važne su u povijesti Arhiva i zbog dvije vrlo vrijedne akvizicije, ostavštine Izidora i Štefe Kršnjavi, ${ }^{37}$ te donacije Želimira Koščevića, dotadašnjeg voditelja Galerije Studentski centar, koji je predao cjelokupnu sređenu arhivu galerijskog djelovanja iz razdoblja od I966. do I978. godine (sl. 9).

Ponovni preustroj organizacije rada unutar Akademije rezultirao je I978. godine osnutkom Istraživačkog centra JAZU, koji je u svojstvu radne jedinice objedinio osamnaest istraživačkih jedinica u okviru četiri odjela. Arhiv tada postaje dijelom Kabineta za arhitekturu i urbanizam. ${ }^{38}$ U tom razdoblju započinje dugogodišnja i sustavna suradnja s Leksikografskim zavodom na izradi natuknica o likovnim umjetnicima za potrebe Biografskog leksikona, koja traje do danas. Nakon r9gr. i preimenovanja Jugoslavenske u Hrvatsku akademiju znanosti i umjetnosti Arhiv s Kabinetom postaje dijelom znanstveno-istraživačkih jedinica ${ }^{39}$ i u tom se administrativnom okviru nalazi do danas. Devedesete su intenziviranim procesima kulturno-nacionalne identifikacije pojačale interes za nacionalnu povijest, čime su posebno popularizirani arhivi. Taj interes nije zaobišao ni zbirke Arhiva za likovne umjetnosti, zahvaljujući kojem su
32 Djelovanje članova viI. odjela za likovne umjetnosti pedesetih se godina smatralo rigidnim zbog zagovaranja čvrstih pravila državne umjetnosti i koncentrirane moći u selekciji umjetnika za velike tematske izložbe tog vremena. Jedan od glavnih opozicijskih glasova bio je Grga Gamulin, koji je u čestim polemikama s Krstom Hegedušićem zamjerao poteze Odjela i isticao nemogućnost djelovanja struke povjesničara umjetnosti u sukreiranju tadašnje likovne scene i izložbene aktivnosti. U tom kontekstu njihov naglašeni interes za djelatnosti Arhiva za likovne umjetnosti može se tumačiti i kao prepoznata mogućnost za dodatnu kontrolu u kreiranju umjetničke politike. Tih godina članovi Odjela za likovne umjetnosti bili su: Vladimir Becić, Antun Augustinčić (dop. od I940., pravi I947.), Tomislav Krizman (dop. I928., pravi I947.), Vanja Radauš (član od r947.), Marino Tartaglia (član od I947.), Đuro Tiljak (član od ı947.), Krsto Hegedušić (član od I948.), Frano Kršinić (član od I948.), te dopisni članovi Cvito Fisković, Vinko Žganec, Drago Galić (ı950.), Mladen Kauzlarić (I950.), Josip Seissel (ı950.), Lavoslav Horvat (I95ı.), Jerolim Miše (I952.).

33 Iz zapisnika primopredaje saznajemo veličinu preuzetih zbirki: 2I86 kataloga, II54 fascikala umjetnika u Zbirci dokumentacije, 27 kompleta uvezanih novina, I2 ostavština u Zbirci arhivalija, te Io46 autora u Fototeci.

34 Doris Baričević (u Arhivu od r949. do r993.) vodila je Zbirku kataloga, Dimitrije Mića Bašičević (u Arhivu od I955. do I959.) bio je zadužen za sredivanje Fototeke, a Vladimira Tartaglia Kelemen (u Arhivu od I959. do I996.) za Zbirku dokumentacije. Vjekoslava Kerdić (u Arhivu od I954. do I98I.) i Ružica Mikulan (u Arhivu od I959. do 2004.) radile su kao administratorice.

35 Iz dopisa Miodraga Protića, direktora Muzeja savremene umetnosti iz Beograda od I9. svibnja I970. saznajemo da je Marija Pušić, kustosica i voditeljica Odjela umjetničke dokumentacije, boravila u Arhivu u nekoliko navrata, gdje je presnimavala dokumentaciju i biografije umjetnika. ARLIKUM, Registraturno gradivo.

36 DORIS BARIČEVIĆ, Proljetni salon; VLADIMIRA TARTAGLIA KELEMEN, Četvrti decenij, u: 6o godina slikarstva i kiparstva u Hrvatskoj, katalog izložbe, Zagreb, I96I., I5-I7; 23-25; VLADIMIRA TARTAGLIA KELEMEN, Izložba I874. u Narodnom domu: prilog proučavanju prvih umjetničkih izložaba u Hrvatskoj, u: Zbornik Historijskog instituta JAZU, 5 (I963.), 377-386; VLADIMIRA TARTAGLIA KELEMEN, Ferdinand Quiquerez u Italiji: prilog za slikarevu biografiju, u: Radovi Arhiva JAZU, I (I972.), Io9-132; VLADIMIRA TARTAGLIA KELEMEN, Pisma Izidora Kršnjavog ı874-ı878., u: Radovi Arhiva JAZU, 2 (I973.), I75-220.

37 Građa otkupljena I974. danas je pohranjena u osamnaest kutija, a sadržava korespondenciju, osobne dokumente, fotografije, bilježnice sa skicama i rukopise.

38 Ravnateljica Kabineta za arhitekturu i urbanizam od I979. do I989. godine bila je povjesničarka umjetnosti i konzervatorica Ana Deanović.

39 Od r989. godine do danas ravnatelj je Kabineta za arhitekturu i urbanizam akademik Velimir Neidhardt. 


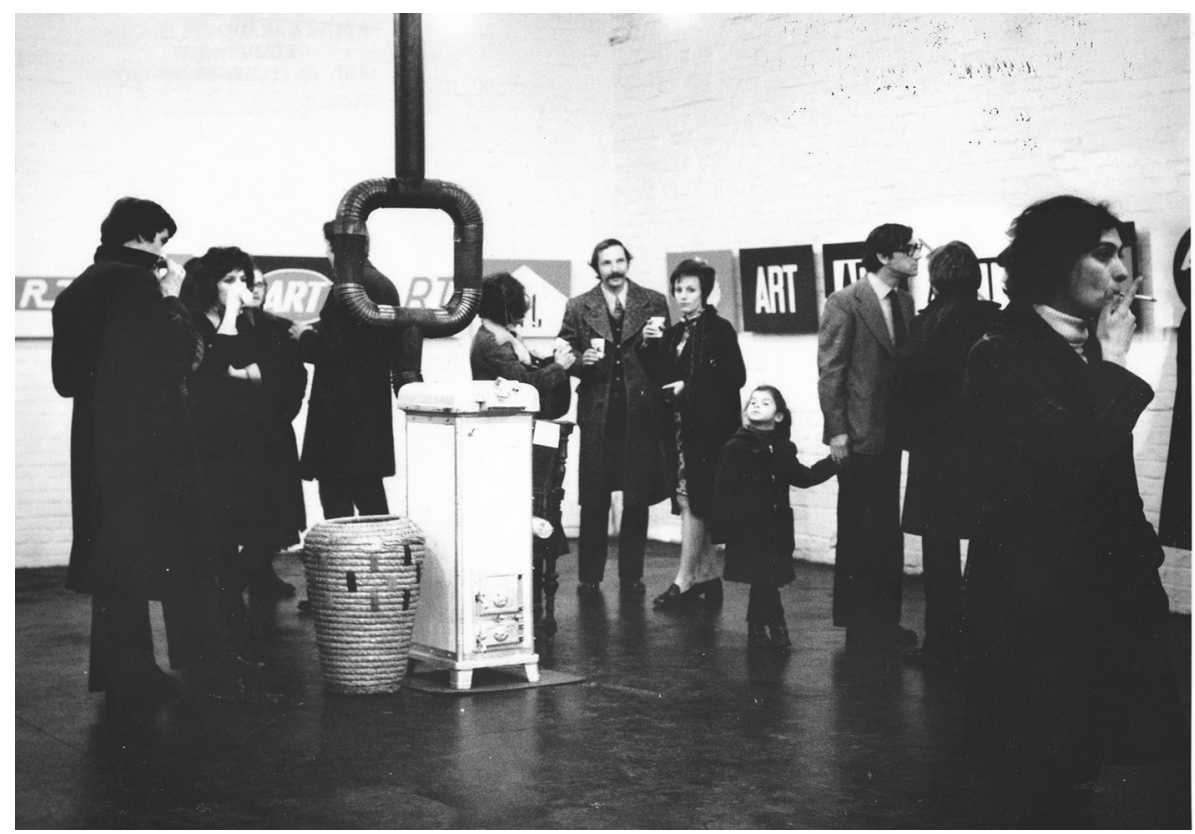

Slika 9

S otvaranja izložbe Bućan art u Galeriji Studentskog centra, Zagreb, 9. veljače I973. ARLIKUM HAZU - Arhiv Galerije SC I966. - I978., $\mathrm{SC}-3 / \mathrm{f} 9$, foto: Petar Dabac

realizirani brojni važni kulturni projekti, stručni i znanstveni skupovi te monografije i izložbe. ${ }^{40}$ Godine 2003. započinje novo razdoblje u razvoju institucije. Uz uspješnu realizaciju vrlo zahtjevna preseljenja Arhiva u prikladniji, novoadaptirani prostor u Gundulićevoj 24, ${ }^{41}$ nova generacija djelatnica, na čvrstim zasadama svojih prethodnica, oblikovala je smjernice daljeg razvoja institucije u suvremenom, tehnološki zasnovanu kulturnom i društvenom kontekstu 2I. stoljeća. Učiniti Arhiv vidljivijim i prisutnijim u kulturnoj i znanstvenoj zajednici nametnulo se kao primarna zadaća. ${ }^{42}$ Istovremeno se nastojalo Arhiv približiti korisnicima bržom komunikacijom traženih informacija. U tom smislu godine koje slijede postupno uvode Arhiv u novu informatičko-digitalnu eru. Od I998. godine započinje se sa sustavnom informatizacijom, ${ }^{43}$ upisom zbirki u računalne baze podataka, što je ujedno bio preduvjet digitalizacije građe, kojoj se pristupilo 20og. godine. Za prvu fazu digitalizacije ${ }^{44}$ odabrana je Zbirka kataloga iz razdoblja od i89o. do I950. kako bi se spriječilo dalje propadanje raritetnih primjeraka zbog česte manipulacije. Unutar te kategorije zaokružene su pojedine umjetničke grupe i pojave, poput Proljetnog salona, Hrvatskog društva umjetnosti i sl. Od 2oro. Arhiv je uključen u zajednički projekt Digitalne zbirke Hrvatske akademije znanosti i umjetnosti DiZbi (dizbi. hazu.hr) ${ }^{45}$ koji je omogućio korisnicima slobodan pristup digitaliziranim sadržajima mrežnim putem, bez ograničenja analognog svijeta. Dosad je postavljeno 403 kataloga te više od 200 fotografija iz Fototeke i Arhiva SC-a. Svi su digitalni zapisi obrađeni detaljnim metapodacima, od kojih su mnogi normirani te zbog toga lako i jednostavno pretraživi. Zahvaljujući platformi ArhivX, koja uključuje i uslugu semantičke mreže, omogućen je svojevrstan cross over digitalnih zapisa Arhiva i
40 Obilježavanje go. obljetnice ALU s prigodnom monografijom, znanstveni skup o Viktoru Kovačiću, monografska izložba Vjekoslava Karasa itd.

4I Dvorišna zgrada u Gundulićevoj 24 sagrađena je dvadesetih godina 2o. stoljeća, a u posjed Jugoslavenske akademije dolazi r948. godine, kada se adaptira za smještaj Izdavačkog odjela i tiskare. Osamdesetih godina ondje je smješteno uredništvo časopisa Oko a devedesetih tiskara IKRO Mladost. Osim Arhiva, 2003. godine u Gundulićevu useljavaju i Zavod za ornitologiju HAZU, Kabinet za istraživanje i standardizaciju imunoloških supstancija HAZU te Zavod za povijest medicinskih znanosti HAZU.

42 Prva prezentacija Arhiva, njegove djelatnosti i zbirki bila je namijenjena studentima povijesti umjetnosti, koji su se dotad vrlo rijetko služili Arhivom. Zahvaljujući odličnoj suradnji i potpori kolega s Odsjeka za povijest umjetnosti Filozofskog fakulteta Sveučilišta u Zagrebu ta je suradnja sada izvrsna.

43 Prvi korak prema informatizaciji Arhiva učinjen je još I993. godine, kada je prema idejnoj koncepciji i inicijativi tadašnje znanstvene asistentice Arhiva, Mirjane Repanić-Braun, osmišljen projekt izrade računalne baze podataka za likovnu umjetnost I9. i 2o. stoljeća. Softver i informatičku opremu financirala je Fondacija Soros. Baze su djelomično formirane, no projekt je ubrzo prekinut zbog gašenja informatičke tvrtke.

44 Projekt digitalizacije započet je uz financijsku potporu Ministarstva kulture RH.

45 Digitalna zbirka Hrvatske akademije znanosti i umjetnosti DiZbi osnovana je 2009., a sadržava digitaliziranu građu četrnaest Akademijinih istraživačkih i muzejsko-galerijskih jedinica te Akademijine Knjižnice. Trenutno obuhvaća više od 31.50o zapisa, a uključuje digitaliziranu građu ovih izvornih formata: knjige, časopisi, kazališne cedulje, rukopisi, mikrofilmovi, note, fotografije, sadreni odljevi, medalje i plakete, umjetničke slike, arhitektonski nacrti i modeli, video. U Europeani dostupne su 24.003 jedinice. 
onih iz ostalih Akademijinih jedinica. Kao jedan od rezultata digitalizacije ostvaren je i multimedijalni projekt virtualnih izložaba u svrhu prezentacije tematski objedinjene digitalizirane građe, započet 20I3. godine izložbom Pablo Picasso, proslava osamdesetog rođendana-Vallauris I96I., ${ }^{46}$ ubrzo objavljena i na portalu Europeana.

Razvoj informacijskih i komunikacijskih tehnologija (ICT) ${ }^{47}$ stvorio je i još stvara nove kontekste djelovanja mnogih ustanova $u$ kulturi pa tako i Arhiva, istovremeno stavljajući pred njih tehnološke izazove, ali i omogućavajući lakše i otvorenije pristupe digitaliziranoj građi. U tom se procesu otvaraju i mnoga pitanja o pristupu, ali i prikupljanju on-line dokumenata i drugih sadržaja umjetničke prakse, na koja Arhiv za likovne umjetnosti nastoji odgovoriti. Usporedo s digitalnim nastavlja se i tzv. konvencionalni razvoj te baštinske ustanove. Njezini pak resursi neprestano rastu, ${ }^{48}$ svjedočeći o ekspanziji domaće umjetničke produkcije, te tim zbrojem jedinstvenih znanja participiraju u sveukupnoj nacionalnoj bazi hrvatske umjetnosti.

\section{(1) (1)}

Arhiv za likovne umjetnosti Hrvatske akademije znanosti i umjetnosti: I937.-20ı6. / Andreja Der-Hazarijan Vukić/ CC BY / 4.0

DOI: https://doi.org/ıo.3ı664/z4khpu.Io
46 Izložba je temeljena na fotografijama iz ostavštine Vesne Barbić, koja je na proslavu Picassova rođendana u Vallaurisu pozvana u svojstvu ravnateljice Gradske galerije suvremene umjetnosti. Ostavštinu je darovala Arhivu 2008. godine.

47 ALEKSANDRA UZELAC, Digitalna kulturna dobra u informacijskom društvu između javne domene i privatnog vlasništva, u: Medijska istraživanja ıo/I (2004.), $37^{-} 53$.

48 Naziv Arhiv ne daje sasvim točan opis djelatnosti ustanove. Naime, za razliku od ostalih arhiva, čije se arhivsko gradivo popunjava isključivo otkupima i donacijama arhivske građe, u Arhivu za likovne umjetnosti ono se svakodnevno stvara praćenjem dnevnog tiska i periodike, praćenjem i upisivanjem izložbene aktivnosti, prikupljanjem kataloga i popratne dokumentacije recentnih izložaba, proširivanjem baze umjetnika novim imenima tek diplomiralih umjetnika. Dinamika popunjavanja zbirki najbolje je vidljiva u usporedbi s prijašnjim brojkama (bilj. 33): Kartoteka autora-I5.462; Zbirka dokumentacije umjetnika-2.864 zasebnih dosjea umjetnika; Zbirka kataloga-26.I34; Zbirka ostavština-27; Fototeka-406 kutija, oko 27.ooo fotografija; Zbirka hemeroteke I950.-2016., 200 kutija. 